\title{
The Diversity of Understory (Shrubs And Herbs) in Mount of Nglanggeran
}

\author{
Didik Zulfahmi Akbar ${ }^{*}$, Widodo, Tanti Agustina \\ Biology Education Department, Faculty of Science and Technology, UIN Sunan Kalijaga \\ Jl. Marsda Adisucipto 55281 Yogyakarta, Indonesia. Tel. + 62-274-540971, Fax. + 62-274-519739 \\ *Email: didikzulfahmiakbar@gmail.com
}

\begin{abstract}
Mount of Nglanggeran is areas that have diversity of unique flora. This area is uninhabited, so many diversity flora that not identified and have not experienced exploration. Therefore, further exploration of plant diversity is needed. The research is aim to inventory, documentation, and find out the diversity of understory (shrubs and herbs) on Mount Nglanggeran. This research used survey and exploration methods. The researchers documented shrubs and herbs species. Based on result, found 44 family consist of 144 species shrubs and herbs. Those species are flora that has specifically characteristics.
\end{abstract}

Keywords: Mount of Nglanggeran, Shrubs and Herbs, Understory

\section{INTRODUCTION}

Mount of Nglanggeran is located at Nglanggeran village, Patuk sub-district, Gunung kidul district. According to Surono (2008) this region was formed on the tertiary era when the early miocene to the middle Miocene $( \pm 23$ million years ago). Geologically and geomorfologically this area is interesting, these conditions are influence structure and the composition of vegetation that flora grows. Mount of Nglanggeran has many diversity of wild flora (some species have not been identified regarding local knowledge) and unique flora (some species have specifically characteristic). According to Widodo (2015), some species are founded also have the same characteristic with the species in another place, for example Sulawesi, India, and Sri Langka. Eventually this conditions encourage researchers for studying flora diversity in this region.

The meaning of diversity is different conditions or have different forms or character. The diversity of species in an area can be observed on two levels, there are number of species same life form and present of species with different life form (Ewusie, 1990). Mount of Nglanggeran is region dominated with understory. Especially diversity of shrubs and herbs. Understory is plants vegetation which is under the forest stand except tree regenerations includes grass, herbs, and shrubs. The types of understory have character annual, biennial, and perennial. The type of distribution occurs randomly, clustered and equally. Commonly understory are able to grow-well under canopy. A few species understory are able to grow under the sun directly. Usually found in cluster, so that it form shrubs (Robert and Thomas, 1998). Ecologically understory vegetation are able to observe according to plant life forms (Sumardi and Widyastuti, 2004).

In tropical forests stratification, understory includes shrubs, sub-shrub, and layers of ground cover
(Soerinagara and Indrawan, 2008). Herbaceus is a soft trunked plants and contains a lot of water (Pirnanda, 2016). Muller-Dombois and Ellenberg (1974) mention, herbs is plants without woody stems living in ground cover. Herbs are divided in three cluster that are ferns, graminoids, forbs. While the shrubs is plants that are not large in size, the woody stems but small and branching near of surface (Tjitrosoepomo, 1994). According to Haris (1979), usually, the shrubs smaller than the tree, shrubs usually have a height of less than 5 meters. The mostly of shrubs have many bud at the base and along stems.

Diversity exploration of flora are needed because for documenting and diversity inventory of the species genetic, learn the distribution of flora, learn of taxonomy, conservation effort for prevent extinction, learn molecular structure of plants, learn secondary metabolite, etc. (Nurbani, 2015). This research have aims for documented diversity of understory (shrubs and herbs) in Mount of Nglanggeran. The data of result can be help for studying a variety of plants species the shrubs and herbs in systematic and visual. The existence of the species diversity in Mount Nglanggeran needs to be disseminated to present the richness of flora on the island of Java. Currently, the knowledge about the diversity of flora on Java island, especially wild plants is less known (Widodo, 2017).

\section{MATERIALS AND METHODS}

\section{Study Area}

The research was conducted on the main climbing route of Mount Nglanggeran which is an ecotourism area in Gunungkidul, Yogyakarta, Indonesia (Figure 1) from Januari 2018 to May 2018. Photographic documentation was done as the first step of the identification process. The photoshoot focused on 
stems, leaves, and inflorescence morphology to simplify identification process. Identification were done along with observe the understory vegetation.

\section{Tools and Materials}

Equipment used for observation and data collection consists of digital cameras, worksheet about data species, and plants identification book.

\section{Work Procedure}

The working procedures were as follows: photographing and observation of specimen in situ, identification with compared to illustrations in Flora of Java (Backer and Backhuizen, 1963). Flora (Steenis, 2006), Encyclopedi of Flora (LIPI, 2009), and other existing literature, from website naturesloveyou.sg, plantsystematics.org, plannet.com, checking and matching with herbarium types and illustrations/drawings in the literature to identify the specimen.

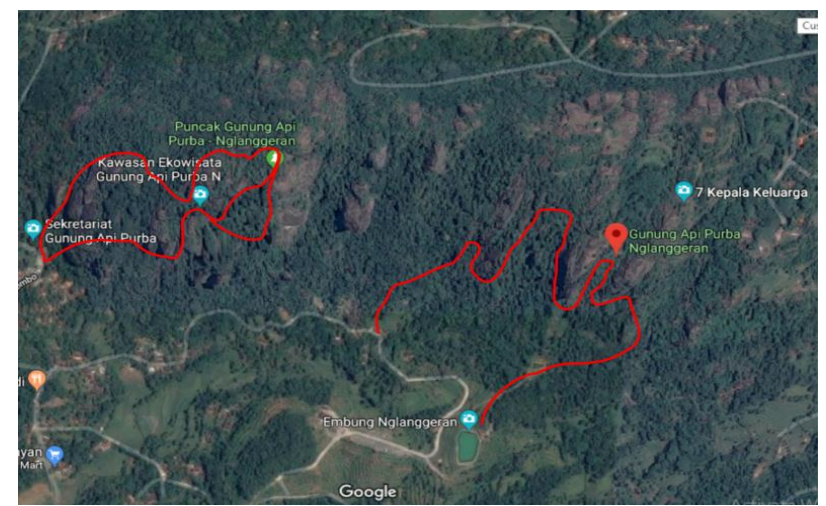

Figure 1. Climbing route for exploration and observation.

\section{RESULT AND DISCUSSION}

The result from this research is inventory of understory in Mount Nglanggeran. Data presented based on life form (habitus), which includes understory are shrubs, herbs, and several lianas. This is show the result of diversity understory:

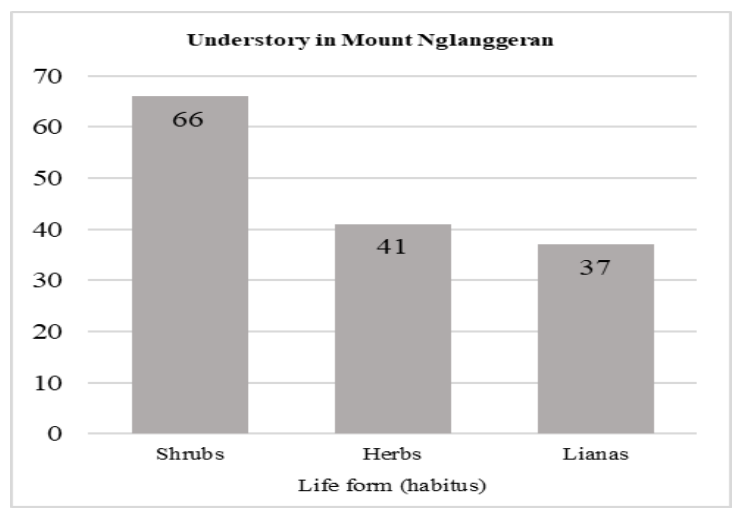

Figure 2. The total distribution of understory species that found on Mount Nglanggeran.

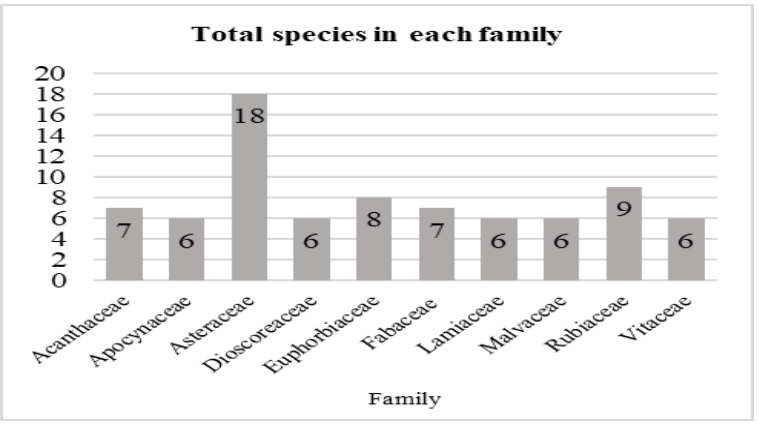

Figure 3. Ten family of understory that have high number in Mount Nglanggeran.

Based on life form (habitus), understory that dominate in Mount Nglanggeran is shrubs. The shrubs consist 66 species, 41 herbs species, and 37 lianas species. The shrubs are very easily to find, because they reproduce using seeds and can adapt quickly. Shrub communities that dominate around climbing path are Memecylon caeruleum (Figure 4) and Ardisia humilis (Figure 5). The species of Memecylon caeruleum grows in forests with dry land. The spread is also very easy through seeds (Bharathi et al., 2016). So that the species of Memecylon caeruleum dominates more on Nglanggeran. The plants of Memecylon caeruleum are more commonly found associated with Ardisia humilis, Pavetta indica, Melastoma malabathicum. and Psychotria sp. (Widodo, 2015).

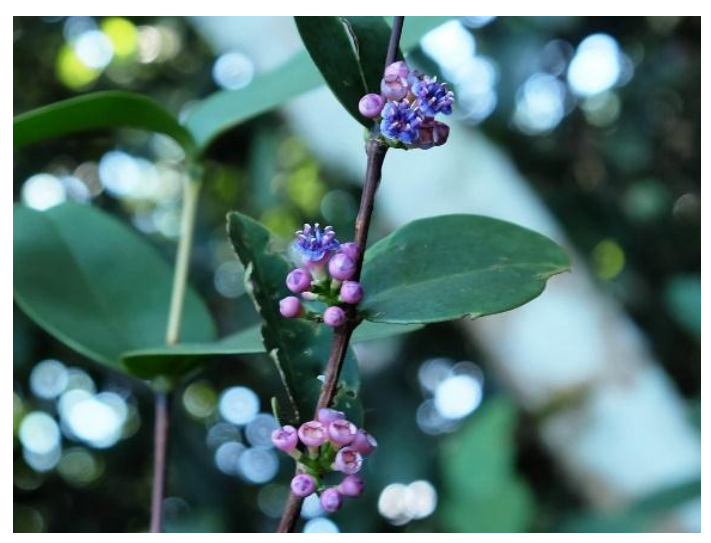

Figure 4. Memecylon caeruleum.

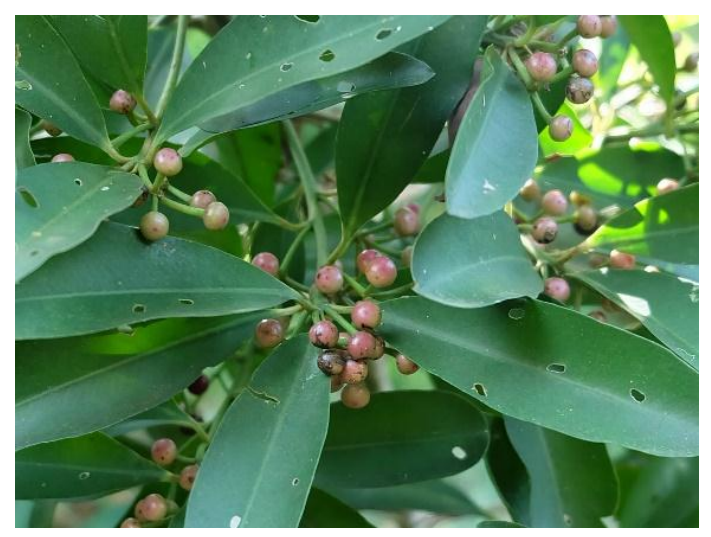

Figure 5. Ardisia humi. 
Based on the identification results, there were 144 species of shrubs and herbs found in Nglanggeran, with a total of 46 families. The plant list of (shrubs and herbs) species were found in Mount Nglanggeran.

Table 1. Plant list of shrubs and herbs in Nglanggeran.

\begin{tabular}{|c|c|c|c|c|c|c|c|}
\hline No & Family & Species & $\begin{array}{l}\text { Life-form } \\
\text { (Habitus) }\end{array}$ & No & Family & Species & $\begin{array}{l}\text { Life-form } \\
\text { (Habitus) }\end{array}$ \\
\hline \multirow[t]{7}{*}{1} & Acanthaceae & Andrographis paniculata & $\mathrm{H}$ & 16 & Dilleniaceae & Tetracera scandens & $\mathrm{S}$ \\
\hline & & Asystasia gangetica & $\mathrm{H}$ & 17 & Dioscoreaceae & Dioscorea alata & $\mathrm{L}$ \\
\hline & & Blechum pyramidatum & $\mathrm{H}$ & & & Dioscorea bulbifera & $\mathrm{L}$ \\
\hline & & Dicliptera foetida & $\mathrm{H}$ & & & Dioscorea hispida & $\mathrm{L}$ \\
\hline & & Ruellia napifera & $\mathrm{H}$ & & & Dioscorea nummularia & $\mathrm{L}$ \\
\hline & & Strobilanthes crispus & $\mathrm{S}$ & & & Dioscorea oppositifolia & $\mathrm{L}$ \\
\hline & & Thunbergia fragrans & $\mathrm{L}$ & & & Dioscorea pentaphylla & $\mathrm{S}$ \\
\hline 2 & Amaranthaceae & Cyathula prostate & $\mathrm{H}$ & 18 & Euphorbiaceae & Acalypha indica & $\mathrm{H}$ \\
\hline 3 & Annonaceae & Popowia sp & $\mathrm{S}$ & & & Bridelia stipularis & $\mathrm{S}$ \\
\hline \multirow[t]{2}{*}{4} & Apiaceae & Centella asiatica & $\mathrm{H}$ & & & Euphorbia heterophylla & $\mathrm{S}$ \\
\hline & & Eryngium foetidum & $\mathrm{H}$ & & & Euphorbia pulcherrima & $\mathrm{S}$ \\
\hline \multirow[t]{6}{*}{5} & Apocynaceae & Anodendron paniculatum & $\mathrm{S}$ & & & Glochidion eriocarpum & $\mathrm{S}$ \\
\hline & & Chonemorpha fragran & $\mathrm{L}$ & & & Jatropha multifida & $\mathrm{S}$ \\
\hline & & Cosmostigma racemosum & $\mathrm{L}$ & & & Phyllanthus muriculatus & $\mathrm{H}$ \\
\hline & & Hoya cumingiana & $\mathrm{S}$ & & & Sauropus sp. & $\mathrm{S}$ \\
\hline & & Hoya diversifolia & $\mathrm{L}$ & 19 & Fabaceae & Centrosoma pubescens & $\mathrm{L}$ \\
\hline & & Rauvolfia verticillata & $\mathrm{S}$ & & & Mimosa pudica & $\mathrm{S}$ \\
\hline 6 & Araliaceae & Schefflera arboricola & $\mathrm{S}$ & & & Flemingia sp. & $\mathrm{S}$ \\
\hline \multirow[t]{18}{*}{7} & Asteraceae & Acmella repens & $\mathrm{H}$ & & & Phyllodium pulchellum & $\mathrm{S}$ \\
\hline & & Ageratum conyzoides & $\mathrm{S}$ & & & Pseudarthria viscida & $\mathrm{H}$ \\
\hline & & Bidens pilosa & $\mathrm{S}$ & & & Puereria phaseloides & $\mathrm{S}$ \\
\hline & & Blumea sp. & $\mathrm{S}$ & & & Uraria crinite & $\mathrm{S}$ \\
\hline & & Chromolaena odorata & $\mathrm{S}$ & 20 & Gentianaceae & Fagraea ceylanica & $\mathrm{S}$ \\
\hline & & Cosmos caudatus & $\mathrm{S}$ & 21 & Gesneriaceae & Epithema horsfeldii & $\mathrm{H}$ \\
\hline & & $\begin{array}{l}\text { Crassocephalum } \\
\text { crepidioides }\end{array}$ & $\mathrm{H}$ & 22 & Helicteraceae & Helicteres hirsute & $\mathrm{S}$ \\
\hline & & Elephantopus scaber & $\mathrm{H}$ & 23 & Lamiaceae & Clerodendrum paniculatum & $\mathrm{S}$ \\
\hline & & Elephantopus spicatus & $\mathrm{H}$ & & & Gophostemma javanicum & $\mathrm{S}$ \\
\hline & & Emilia sanchifolia & $\mathrm{H}$ & & & Hyptis suavelons & $\mathrm{H}$ \\
\hline & & Erigeron sumatrensis & $\mathrm{S}$ & & & Leucas sp & $\mathrm{H}$ \\
\hline & & Porophyllum ruderale & $\mathrm{H}$ & & & Leucas aspera & $\mathrm{H}$ \\
\hline & & Spilanthes costata & $\mathrm{H}$ & & & Plectranthus sp. & $\mathrm{H}$ \\
\hline & & Synedrella nudiflora & $\mathrm{H}$ & 24 & Lindernaceae & Torenia sp. & $\mathrm{H}$ \\
\hline & & Vernonia cinerea & $\mathrm{H}$ & 25 & Loranthaceae & Scurrula parasitica & $\mathrm{S}$ \\
\hline & & Wedelia trilobata & $\mathrm{H}$ & 26 & Lythraceae & Lawsonia inermis & $\mathrm{S}$ \\
\hline & & Tithonia diversifolia & $\mathrm{S}$ & 27 & Malvaceae & Abelmoschus moscatus & $\mathrm{S}$ \\
\hline & & Ageratina adenophora & $\mathrm{S}$ & & & Hibiscus surattensis & $\mathrm{S}$ \\
\hline 8 & Balsaminaceae & Impatiens sp. & $\mathrm{H}$ & & & Sida acuta & $\mathrm{S}$ \\
\hline 9 & Boraginaceae & Ehretia microphylla & $\mathrm{S}$ & & & Sida retusa & $\mathrm{S}$ \\
\hline 10 & Capparaceae & Capparis micracantha & $\mathrm{S}$ & & & Urena lobata & $\mathrm{S}$ \\
\hline \multirow[t]{2}{*}{11} & Celastraceae & Celastrus scandens & $\mathrm{L}$ & & & Waltheria indica & $\mathrm{S}$ \\
\hline & & Celastrus sp. & $\mathrm{S}$ & 28 & Melastomataceae & Clidemia hirta & $\mathrm{S}$ \\
\hline 12 & Colchicaceae & Gloriosa superba & $\mathrm{H}$ & & & Melastoma malabathricum & $\mathrm{S}$ \\
\hline \multirow[t]{5}{*}{13} & Convolvulaceae & Argyreia mollis & $\mathrm{L}$ & & & Memecylon caeruleum & $\mathrm{S}$ \\
\hline & & Ipomea lacunose & $\mathrm{L}$ & 29 & Menispermaceae & Stephania hernandifolia & $\mathrm{L}$ \\
\hline & & Ipomea purpurea & $\mathrm{L}$ & & & Tinospora glabra & $\mathrm{L}$ \\
\hline & & Merremia hastate & $\mathrm{L}$ & 30 & Moraceae & Maclura cochinchinensis & $\mathrm{S}$ \\
\hline & & Ipomea pes-tigridis & $\mathrm{L}$ & & & Malaisia scandens & $\mathrm{S}$ \\
\hline 14 & Costaceae & Costus speciosus & $\mathrm{H}$ & 31 & Oleaceae & Jasminum pubescens & $\mathrm{S}$ \\
\hline \multirow[t]{3}{*}{15} & Cucurbitaceae & Tricosanthes villosa & $\mathrm{L}$ & 32 & Oxalidaceae & Biophytum reinwardtii & $\mathrm{H}$ \\
\hline & & Mimordica charantia & $\mathrm{L}$ & & & Oxalis corniculata & $\mathrm{H}$ \\
\hline & & Tricosanthes tricuspidata & $\mathrm{L}$ & & & Oxalis sepium & $\mathrm{H}$ \\
\hline
\end{tabular}




\begin{tabular}{|c|c|c|c|c|c|c|c|}
\hline No & & Species & $\begin{array}{l}\begin{array}{l}\text { Life-form } \\
\text { (Habitus) }\end{array} \\
\end{array}$ & No & Family & Species & $\begin{array}{l}\begin{array}{l}\text { Life-form } \\
\text { (Habitus) }\end{array} \\
\end{array}$ \\
\hline & & Coccinia grandis & $\mathrm{L}$ & & & Pavetta indica & $\mathrm{S}$ \\
\hline 33 & Passifloraceae & Passiflora suberosa & $\mathrm{L}$ & & & Pentas lanceolata & $\mathrm{S}$ \\
\hline \multirow[t]{5}{*}{34} & Piperaceae & Peperomia sp & $\mathrm{H}$ & & & Psychotria celebica & $\mathrm{S}$ \\
\hline & & Peperomia pellucida & $\mathrm{H}$ & & & Vangueria spinosa & $\mathrm{S}$ \\
\hline & & Piper aduncum & $S$ & 40 & Rutaceae & Clausena excavate & $\mathrm{S}$ \\
\hline & & Piper nigrum & $\mathrm{S}$ & 41 & Smilacaceae & Smilax anceps & $\mathrm{L}$ \\
\hline & & Piper retrofactum & $\mathrm{S}$ & & & Smilax celebica & $\mathrm{L}$ \\
\hline 35 & Primulaceae & Ardisia humilis & $S$ & & & Smilax glauca & $\mathrm{L}$ \\
\hline \multirow[t]{5}{*}{36} & Ranunculaceae & Clematis sp. & $\mathrm{L}$ & 42 & Solanaceae & Solanum torvum & $\mathrm{S}$ \\
\hline & & Clematis sp. & $\mathrm{L}$ & 43 & Thymelaeaceae & Phaleria octandra & $S$ \\
\hline & & $\begin{array}{l}\text { Unidentified } \\
\text { Ranunculacae }\end{array}$ & $\mathrm{L}$ & 44 & Urticaceae & Laportea interrupta & $\mathrm{H}$ \\
\hline & & $\begin{array}{l}\text { Unidentified } \\
\text { Ranunculacae }\end{array}$ & $\mathrm{L}$ & & & Pauzolzia zeylanica & $\mathrm{H}$ \\
\hline & & $\begin{array}{l}\text { Unidentified } \\
\text { Ranunculacae }\end{array}$ & $\mathrm{L}$ & 45 & Verbenaceae & Clerodendron serratum & $\mathrm{S}$ \\
\hline \multirow[t]{2}{*}{37} & Rhamnaceae & Zizhipus oenoplia & $S$ & & & Lantana camara & $\mathrm{S}$ \\
\hline & & Zizhipus mucronata & $S$ & & & Stachytarpheta jamaicensis & $\mathrm{S}$ \\
\hline 38 & Roscaeae & Rubus moluccanus & $\mathrm{L}$ & 46 & Vitaceae & Cayratia molissima & $\mathrm{L}$ \\
\hline \multirow[t]{5}{*}{39} & Rubiaceae & Borreria laevis & $\mathrm{H}$ & & & Cissus repens & $\mathrm{L}$ \\
\hline & & Borreria ocymoides & $\mathrm{H}$ & & & Leea asiatica & $\mathrm{S}$ \\
\hline & & Hedyotis corymbusa & $\mathrm{H}$ & & & $\begin{array}{l}\text { Tetrastigma } \\
\text { leucostyphallum }\end{array}$ & $\mathrm{L}$ \\
\hline & & Hedyotis verticillata & $\mathrm{H}$ & & & Vitis discolour & $\mathrm{L}$ \\
\hline & & Mussaenda sp. & $S$ & & & Vitis riparia & $\mathrm{L}$ \\
\hline
\end{tabular}

Information: $\mathrm{S}=$ Shrubs $\mathrm{H}=$ Herbs $\mathrm{L}=$ Lianas

Based on the table and graph above, explains that the Asteraceae families were understory that has the largest number of species, Asteraceae (18 species), then the Rubiaceae family ( 9 species), Euphorbiaceae (8 species), Acanthaceae and Fabaceae (7 species) Apocynaceae, Dioscoreaceae, Lamiaceae, Malvaceae, and Vitaceae (6 species). Based on exploration, the Asteraceae family found in the Mount Nglanggeran grows wild in various locations. This plant often grows in the undercanopy and places that are exposed to direct sunlight.

Asteraceae are families that has high number diversity in Mount Nglanggeran and Asteraceae were the second largest in the kingdom Plantae (Lawrence, 1958). According Cronquist (1981), this families has 20.000 species which consists of 1.100 genera. This amount is less than the number of members of the family Leguminosae which is the largest family in the kingdom of Plantae with a number of species of more than 20,000 species (Banson, 1957).

Researchers found several unique plant and rarely found in all locations. Some plant species were only found in certain habitats so that the plants has not experienced exploration. Researchers try to describe some species that are considered unique and have their own characteristics to grow. These plants include Hoya sp. (Figure 6), Hoya diversifolia (Figure 7), Cayratia molissima (Figure 8), and Smilax anceps. (Figure 9), these plants have a life form (habitus) lianas and vines. Because they live in habitats that were hard to reach, so the researchers was difficult to capture them.

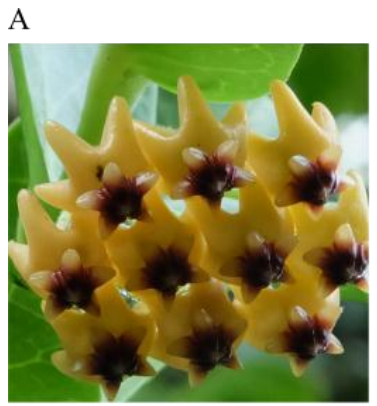

B

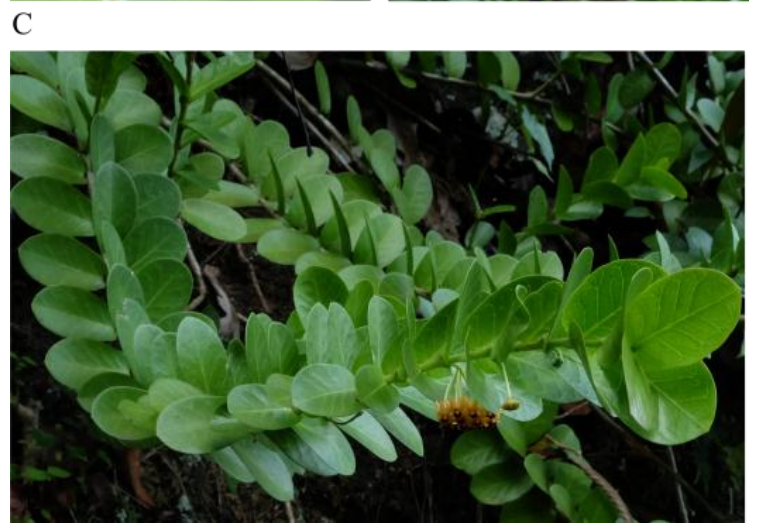

Figure 6. Hoya sp. A. Flowers, B. Leaves and Flowers structure, C. Habitus. 

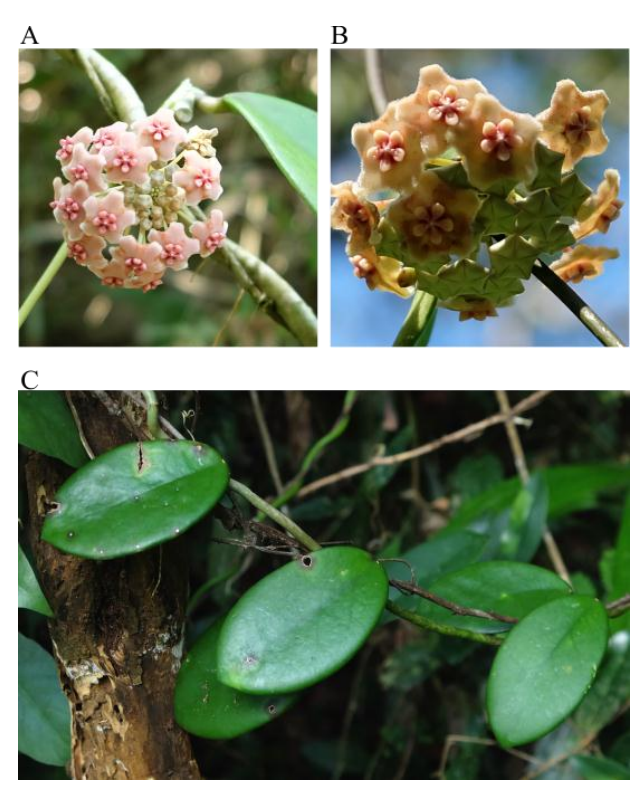

Figure 7. Hoya diversifolia A. Flower, B. Flower and flower buds, C. Habitus.

Hoya sp. (Figure 6) is group of Apocynaceae. This plants is found on the east side in Mount Nglanggeran and epiphyte in rock cliffs. Hoya, also known as wax plants belongs (Siar, 2005). Hoya species are mostly vines and epiphytic climbers (Wanntorp, 2009). Hoya plants are popular ornamentals owing to its waxy foliage and attractive flowers (Borlagdan et al., 2016; Widiarsih et al., 2011). Hoya plants are distributed from India to Pacific islands (Wanntorp et al., 2006). In Asia, it is believed that the southeast region is the center of diversity for Hoya (Rodda and Ang, 2012). Characteristic of Hoya sp is different with Hoya diversifolia. (Figure 9). Both have folia opposite. Some Hoya's species are using to traditional medicine (Jhoanna and Inocencio, 2017). Based on study comparison with herbarium in National Museum D'Histoire Naturelle Philippines, this Hoya sp. alike Hoya cumingiana (MNHN-P-P0063983). The researchers cannot confirm furthermore about this species. Because must be through taxonomically and genetically studies to ensure of status Hoya.

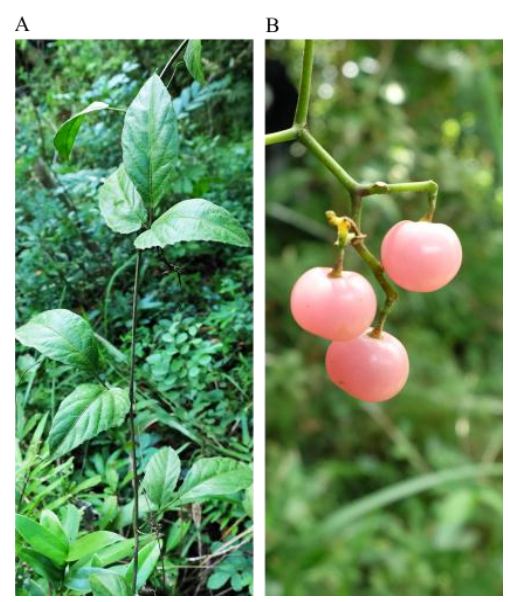

Figure 8. Cayratia mollissima: A. Habitus, B. Fruits.
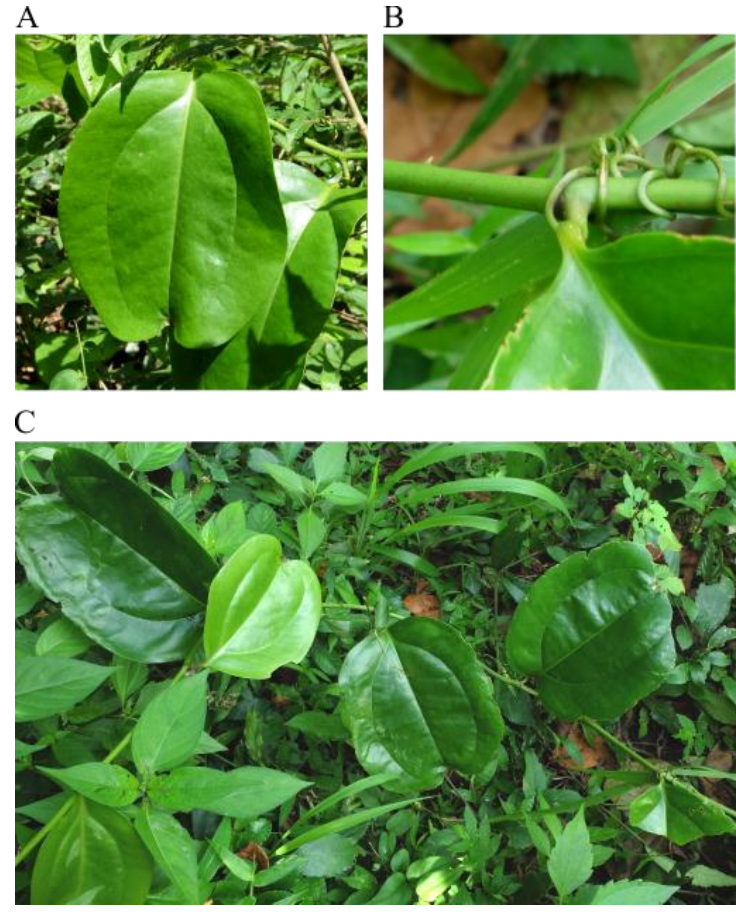

Figure 9. Smilax anceps A. Leaves, B. Caulis and spinosus, C. Habitus.

Cayratia mollissima (Figure 8) was found on the eastern side of the Nglanggeran Mount. This species grows climb in higher plant species. This species is Herbaceous climber. Researchers only found this species in one location. Taxonomically these plants belong to the Vitaceae family, with special features having tendrils and fruit that resemble grapes (Chnar et al., 2011). Cayratia is a tropical and subtropical genus distributed in Asia, Africa, Australia and the Pacific Islands, consisting of 63 species (Wen, 2007). Stem cylindrical, 1-3 $\mathrm{mm}$ diam, branched, hairy with soft villous hairs to $1 \mathrm{~mm}$ long, ridged; tendril $2-3$-furcate, slender, wiry, leaf-opposed, cylindrical, peduncle straight, $1.5-4 \mathrm{~cm}$ by $0.5-1 \mathrm{~mm}$, then bifurcating and coiling for 2-7 cm, hairy as stem. Leaves 3-foliolate, alternate; petiole $1-3.5$ by c. $1 \mathrm{~mm}$, hairy as stem, central petiolule $0.5-1.5 \mathrm{~cm}$ long, lateral petiolules $0.3-$ $0.7 \mathrm{~mm}$ long, hairy as stem; central leaflet blade oval to ovate, $3-6$ by $1.5-3$ cmTrias-Blasi et al., 2011).

Smilax anceps (Figure 9) is a creeper that is covered by many other plants, so the species is difficult to find. Researchers only found this species in one location. This species was found in the east and under other creepers. Smilax anceps is a family of Smilacaceae. Taxonomically, Smilax is difficult genus as the plants are dioecious, show wide phenotypic variation and many herbarium specimens were lack flowers or fruits that make them difficult to identify (Lulut Dwi et al., 2018). This species has spina, cirrhus throughout the stem, and it has folium disticha. Smilax stems are very hard and strong. It has folium compositum, the lamina was laevis. This plant can propagate up to 5 meters (Hyde, 2018). 


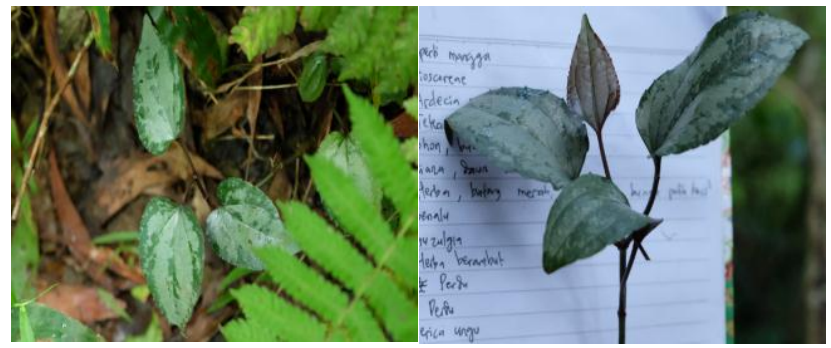

Figure 10. Unidentified Ranunculaceae Life form (habitus) the species from Ranunculaceae that has not been identified.
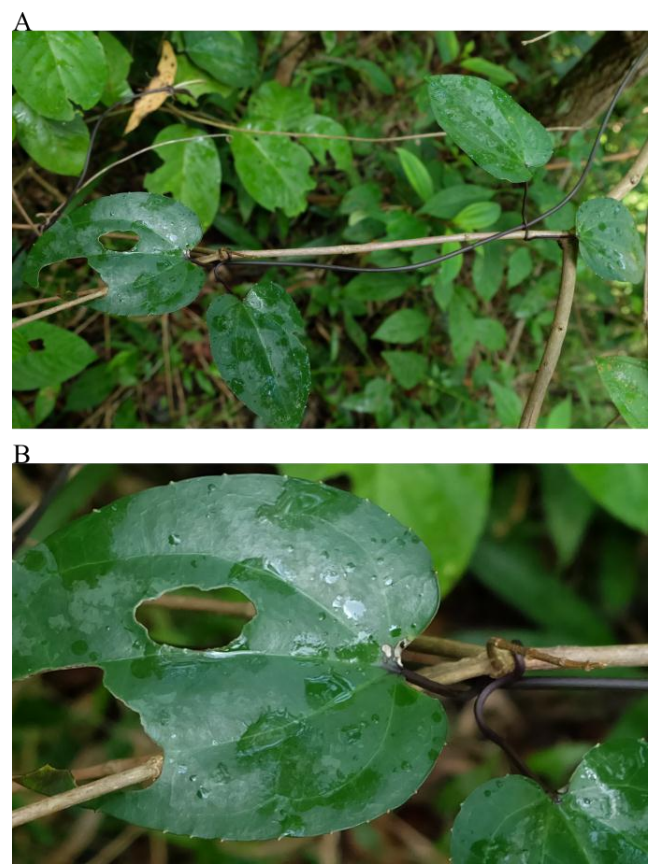

Figure 11. Unidentified Ranunculaceae: A. Habitus, B. Lamina and twisted stem.

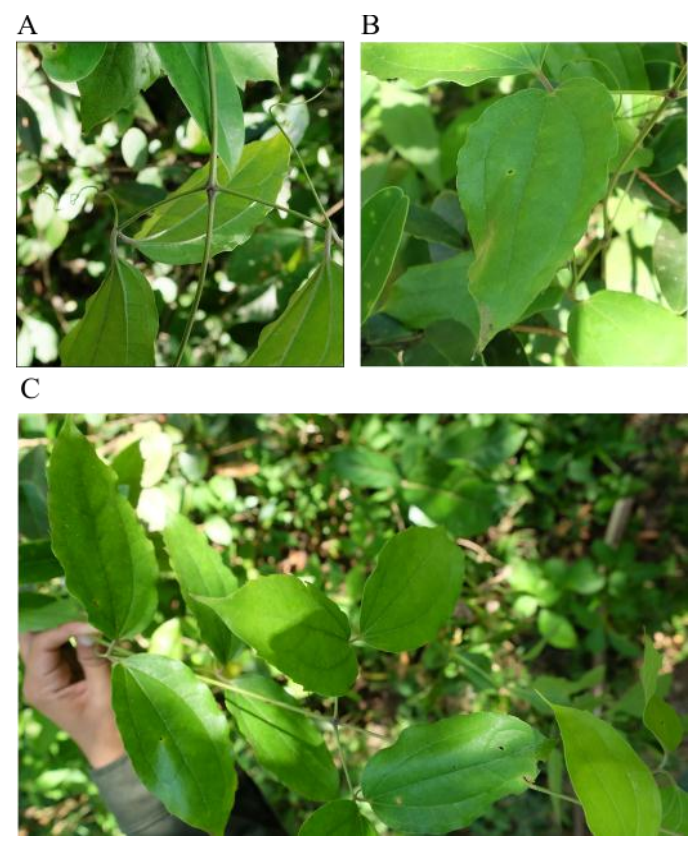

Figure 12. Clematis sp: A. The phyllotaxis and tendrils, B. Lamina, C. Habitus.
Some plant species also attracted the attention of researchers. Because it's difficult to identify. One family of understory that is difficult to identify comes from the Ranunculaceae family (Figures 10, 11, and 12). Ranunculaceae is often regarded as the most primitive of herbaceous angiosperms (Tamura, 1968). Plants from the Ranunculaceae family have diverse morphological features (Khatere et al., 2010). Ranunculaceae has been a source of debate for centuries. some authors refrained from final taxonomic conclusions at the generic level because of incomplete sampling of taxa or markers from Ranunculaceae species (Khatere et al., 2010).

Clematis sp. (Figure 11) is a family of Ranunculaceae. This plant was found on the right side of the climbing path with shady habitat. Researchers only found this species in one location. It is very difficult to find references to this plant. This species adapts well in highland areas (Masoud et al., 2009). This plant is very unique because of the shape of the leaves. The leaves are folium oppositum, with a modified stem to become cirrus (tendrils). Helps to grow climbing (Ralph, 1996).

\section{CONCLUSIONS}

The diversity of understory (shrubs and herbs) in Nglanggeran Mountain consists of 144 species with a total of 44 families. Based on the life form (Habitus), the plants that dominate Nglanggeran Mountain were shrubs. Asteraceae were the most common family. Based on the results of the data collection, there were 66 species of shrubs, 41 species of herbaceous, and 37 species of lianas. Some shrubs and herbs were difficult to find because they have special characteristics habitat to grow.

\section{ACKNOWLEDMENTS}

The researcher would like to thank Dr. Widodo, M.Pd. and Dr. M. Ja'far Luthfi, M.Si as a research advisor as a material expert. Thank you to Agustina as the third author. Thank you to the Nglanggeran Volcano ecotourism manager. Likewise with Biology Education friends.

\section{REFERENCES}

Bharathi TR, Sampath Kumara KK, Prakash HS. 2016. Memecylon Species : A Review of Traditional Information and Taxonomic Description. Department of Studies in Biotechnology, Universityi of Mysore. International Journal of Pharmacy and Pharmacetical Science. Vol. 8.

Borlagdan, M., Aurigue, F. B., Van Altena, I. A., \& Ragasa, C. Y. (2016). Triterpenes from Hoya paziae Kloppenb. Pharmacognosy Journal, 8 (5).

Chnar Najmaddin, Khatijah Hussin and Haja Maideen. 2011 Comparative Anatomical Study between Cayratia Mollissima, 
Pterisanthes Caudigera (Vitaceae) and Leea Indica (Leeaceae). American Journal of Applied Sciences. Vol. 9.

Ewusie, J. Y. 1990. Ekologi Tropika. Bandung : Penerbit ITB

Haris, W. R. 1979. Arboricultur Care of Trees, Shurbs and Vines in the Landscape. Prentice Hall, Englewood, Inc. New Jersey.

Hyde, M.A., Wursten, B.T., Ballings, P., and Coates Palgrave, M. 2018. Flora of Zimbabwe: Species information: Smilax anceps. https://www.zimbabweflora.co.zw/speciesdata/species.php?spec ies_id=114900, retrieved 7 October 2018

Jhoanna O. Santiago and Inocencio E. Buot, Jr. 2017. Checklist of Hoya Species on Palawan Island, Philippines. Journal of Nature. Vol. 1.

Khatere Emadzade, Carlos Lehnebach, Peter Lockhart, Elvira Horandl. 2010. A molecular phylogeny, morphology and classification of genera of Ranunculeae (Ranunculaceae). Taxon. Vol. 59.

Sulistyaningsih, lulut dwi, abinawanto, marlina ardiyani, andi salamah. Short Communication: Phylogenetic analysis and molecular identification of Canar (Smilax spp.) in Java, Indonesia Based on DNA Barcoding Analysis. Jurnal Biodiversitas. 8 (2).

Masoud Sheidai, Meysam Habibi, Dina Azizian, Mahboobeh Khatamsaz. 2009. Cytology and palynology of the Clematis L. species (Ranunculaceae) in Iran. Shahid Beheshti University, G. C., Faculty of Biological Sciences, Tehran, Iran. Acta Bot. Croat. Vol. 1.

Ralph A. Bungard. 1996. Ecological and Physiological Studies of Clematis vitalba L. Lincoln University Canterbury, New Zealand

Robert J. Pabst dan Thomas A. Spies. 1998. Distribution of herbas and shrubs in relation to landform and canopy cover in riparian forests of coastal Oregon. Journal NRC Canada. No. 76.

Rodda, M., \& Ang, W. F. (2012). Hoya caudata Hook. f.(Apocynaceae), a new record for Singapore, and keys to the Hoya species of Singapore. Nature in Singapore, 5, 123-128.

Siar, S.V. Philippine hoyas. Los Baños, Laguna: PCARRD, 2005. 23p.-(Information Bulletin No.237/2005).

Soerianegara. I dan A. Indrawan. 2008. Ekologi Hutan Indonesia. Bogor. Laboratorium Ekologi Hutan. Fakultas Kehutanan. Institut Pertanian Bogor.
Sumardi dan S.M, Widyastuti. 2004. Dasar-dasar Perlindungan Hutan. Yogyakarta: UGM Press.

Surono. 2008. Litostratigrafi dan sedimentasi Formasi Kebo dan Formasi Butak di Pebukitan Baturagung, Jawa Tengah Bagian Selatan. Bandung: Jurnal Geologi Indonesia, Vol. 3 No. 4 Desember 2008: 183-193

Tamura, M. 1968. Morphology, ecology and phylogeny of the Ranunculaceae VIII. (Ranunculaceae of Eastern Asia: general part VIII). Sci. Rep. Osaka Univ. Vol. 17.

Tjitrosoepomo, Gembong. 1994. Taksonomi Tumbuhan (Spermatophyta) cetakan kesebelas. Yogyakarta: Gadjah Mada Universitas Press.

Trias-Blasi A., J.A.N. Parnell, K. Chayamarit, A. Teerawatananon. 2011. Cayratia emarginata (Vitaceae), a new species from Thailand and Vietnam. Blumea (online) http://repository.naturalis.nl/document/565056 retrieved 07 Oktober 2018

Wanntorp, L., Kocyan, A., \& Renner, S. S. (2006). Wax plants disentangled: A phylogeny of Hoya (Marsdenieae, Apocynaceae) inferred from nuclear and chloroplast DNA sequences. Molecular phylogenetics and evolution, 39(3), 722733.

Wen J. 2007. Vitaceae. In: Kubitzki K (ed), The Families and Genera of Vascular Plants. Springer-Verlag, Berlin. Vol. 9.

Widodo and Muhammad Ja'far Luthfi. 2015. Apocynoideae dan Asclepiadoideae dari Pegunungan Baturagung (Gunung Nglanggeran, Gunung Mintorogo, Gunung Parangan, Gunung Gedang, Gunung Ijo): Inisiasi Pencirian dan Konservasi Seminar Nasional Konservasi dan Pemanfaatan Sumber Daya Alam. FKIP UNS.

Widodo and Muhammad Ja'far Luthfi. 2015. Karakteristik Memecylon sp. (Melastomataceae) dari Gunung Nglanggeran, Gunungkidul. Prosemnas Masyarakat Biodiversitas Indonesia. Vol. 1

Widodo and Muhammad Ja'far Luthfi. 2017. Short Communication Characteristic of Anodendron paniculatum (Apocynaceae) in Mount Nglanggeran, Yogyakarta, Indonesia. Jurnal Biodiversitas. 8 (2). 
THIIS PA GE INTENTIONALLY LEFT BLANK 